\title{
Pelatihan Karya Ilmiah Penelitian Tindakan Kelas (PTK) Bagi Guru SMAN 3 Takalar
}

\author{
Alfiah Nurfadhilah AM. Hindi*, Andi Syukriani, Elpisah, Inayanti Fatwa
}

STKIP Pembangunan Indonesia Makassar, Indonesia

\begin{abstract}
Abstrak
Penelitian tindakan kelas menjadi salah satu indikator penting untuk meningkatkan profesionalisme guru. Dengan melakukan PTK, guru-guru diharapkan dapat menemukan sesuatu yang dapat digunakan dalam peningkatan kualitas proses belajar dan mengajar, yang pada akhirnya membantu meningkatkan kulaitas pendidikan secara nasional. Untuk itu, kegiatan ini akan memberikan pelatihan penulisan karya ilmiah penelitian tindakan kelas (PTK) bagi guru. Adapun luaran kegiatan ini mengacu pada tujuan yang diharapkan dari pelaksanaan kegiatan ini adalah: (1) Guru Mampu memahami dan terampil dalam menyusun PTK dan (2) Guru mampu melaksanakan Penelitian Tindakan Kelas. kegiatan ini dapat meningkatkan pengetahuan dan kemampuan peserta pelatihan dalam membuat karya ilmiah penelitian tindakan kelas (PTK) khususnya dalam pembuatan proposal peneltiian tindakan kelas. Selain itu, para peserta mampu menyusun tulisan penelitian tindakan kelas (PTK) sesuai dengan prosedur yang telah disampaikan pada pelatihan.
\end{abstract}

Keywords: Penelitian Tindakan Kelas (PTK) profesionalisme guru, karya ilmiah

\section{Pendahuluan}

Peningkatan kualitas pendidikan menjadi hal penting dalam kemajuan sebuah bangsa dan menjadi tanggung jawab semua pihak; pemerintah, swasta, individu dan lain-lain. Oleh karena banyak hal yang harus dilakukan untuk meningkatkan kualitas pendidikan mulai dari peningkatan alokasi dana bagi sektor pendidikan, peningkatan sarana dan sarana pendidikan, hingga penyediaan guru profesional. Sebagia salah satu faktor yang dapat meningkatkan kualitas pendidikan, profesionalisme guru harus terus ditingkatkan dengan berbagai cara antara lain: mengirim guru untuk mengikuti pelatian dan kursus, studi banding antar institusi pendidikan baik dalam maupun luar negeri, dan yang tidak kalah pentingnya adalah dengan guru melakukan penelitian tindakan kelas (PTK).

Pembelajaran yang berkualitas dapat diwujudkan melalui peningkatan kompetensi guru. Di antara indikator seorang guru berkompeten ialah dapat dilihat dari kemampuannya melakukan penelitian tindakan kelas. Oleh karenanya, penelitian tindakan kelas menjadi penting karena selain meningkatkan kompetensi juga dapat memperbaiki proses pembelajaran. Dalam realitanya keharusan untuk melakukan penelitian tindakan kelas bagi guru belum terlaksana dengan baik secara merata (N. Ulia, dkk, 2019), sehingga tidak jarang banyak di antara guru yang terkendala untuk mengajukan kenaikan pangkat karena ketiadaan penelitian tindakan kelas (D. S. Mulia, 2016). Pernyataan di atas menunjukkan pelatihan penelitian tindakan kelas bagi guru tetap menjadi suatu kegiatan yang urgen untuk dilakukan.

Penelitian tindakan kelas menjadi salah satu indikator penting untuk meningkatkan profesionalisme guru. Hal tersebut tercantum dalam peraturan menteri pendidikan nasional nomor 16 tahun 2007 yang menyatakan salah satu indikator guru profesional adalah mampu melakukan penelitian tindakan kelas (PTK). Peraturan tersebut secara jelas memaksa guru-guru untuk melakukan PTK sebagai salah satu cara peningkatan profesionalisme seorang guru. Dengan melakukan PTK, guru-guru diharapkan dapat menemukan sesuatu yang dapat digunakan dalam peningkatan kualitas proses belajar dan mengajar, yang pada akhirnya membantu meningkatkan kulaitas pendidikan secara nasional.

\footnotetext{
* Corresponding author:

E-mail address: alfiahnurfadhilah2@gmail.com
} 
Menurut Adijaya dan Prayogo (2013) bahwa dengan melakukan penelitian tindakan kelas guru-guru dapat menemukan sesuatu yang dapat digunakan sebagai rancangan atau pedoman untuk meningkatkan kompetensi baik guru itu sendiri maupun siswa yang dapat dilakukan dalam proses belajar mengajar. Walaupun PTK memiliki peranan yang penting dalam peningkatan profesionalisme guru, namun pada kenyataannya banyak guru yang tidak mempu melakukan tindakan kelas. Seperti yang dikatan oleh Rozi (2015) bahwa guru-guru banyak yang mengalami kesulitan dalam melakukan PTK; tidak tahu bagaimana menulis PTK, kurangnya bimbingan dalam penulisan PTK, pengorganisasian ide dan kata-kata, dan sebagainya. Oleh karena itu, untuk meminimalisir masalah dan mendorong guru-guru melakukan PTK, maka perlu dilakukan pelatihan atau pembimbingan bagi guru-guru dalam melakukan PTK. Oleh karena itu, dalam tugas Tri Darma pendidikan tinggi; pengajaran, penelitian, dan pengabdian kepada masyarakat dalam bentuk pelatihan penulisan penelitian tindakan kelas kepada guru-guru untuk meningkatkan profesionalisme guru.

Tuntutan untuk guru yang memiliki kompetensi salah satunya adalah harus melakukan inovasi pembelajaran guna meningkatkan hasil belajar dan di antara langkah untuk mewujudkan inovasi dalam pembelajaran ialah selalu melakukan evaluasi baik terhadap materi, metode, strategi, media, sumber belajar atau sistem lain yang terkait dengan pembelajaran.( Z. A. Ni'mah, 2017) Guna mengevaluasi hal-hal yang terkait dengan pembelajaran guru tidak mungkin meninggalkan tugasnya sebagai pendidik melainkan evaluasi tersebut dilakukan seiring dengan apa yang dilihat, dirasakan dan dialami dalam proses pembelajaran.

\subsection{Permasalahan Mitra}

Penelitian Tindakan Kelas dipandang sebagai bentuk penelitian peningkatan kualitas pembelajaran yang paling tepat, karena selain sebagai peneliti guru juga bertindak sebagai pelaksana proses pembelajaran, sehingga tahu betul permasalahan yang dihadapi dan kondisi ideal yang ingin dicapai (Hunaepi, dkk: 2016).

Hasil-hasil penelitian tindakan kelas yang dilakukan guru selanjutnya diaktualisasikan dalam bentuk laporan tertulis mengikuti kaidah-kaidah penulisan ilmiah dan hasilnya akan dapat berupa karya tulis ilmiah. Tidak sampai di sini, guru selanjutnya dapat mempublikasi tulisan hasil penelitian ke dalam jurnal ilmiah, baik lokal, nasional ter-ISSN, nasional terakreditasi, maupun internasional. Melalui publikasi ilmiah, guru telah dapat mendesiminasikan hasil riset mereka dan dapat menjadi referensi bagi guru atau peneliti lain dalam pengembangan keilmuan berbasis riset.

\subsection{Perumusan Masalah Mitra}

Berdasarkan hasil diskusi dan kesepakatan antara tim pengusul dengan kedua mitra, permasalahan mitra yang menjadi prioritas dan perlu untuk diselesaikan melalui program PKM ini, sebagai berikut:

a. Kurangnya pengalaman guru dalam hal penelitian tindakan kelas

b. Kurangnya pengalaman penulisan ilmiah (penyusunan proposal).

\section{Target Luaran dan Metode}

\subsection{Solusi dan Target Luaran}

Tujuan kegiatan kemitraan masyarakat ini adalah sebagai berikut :

a. Meningkatkan pemahaman dan keterampilan guru SMA dalam menyusun PTK.

b. Meningkatkan pelaksanaan Penelitian Tindakan Kelas melalui pelatihan ini.

Sehingga dalam menghadapi masalah yang diuraikan, maka solusi yang ditawarkan adalah pemberian pelatihan tentang Penelitian Tindakan Kelas. Dalam pemberian pelatihan penelitian tindakan kelas didalamnya terdapat pelatihan pembuatan proposal dan laporan PTK dan juga bagaimana membuat karya ilmiah. Berikut penjabaran solusinya:

a. Pemberian materi tentang konsep dasar Penelitian Tindakan Kelas

b. Pemberian materi tentang Karakteristik Penelitian Tindakan Kelas 
c. Pemberian materi tentang tujuan dan manfaat Penelitian Tindakan Kelas.

Luaran kegiatan mengacu pada tujuan yang diharapkan dari pelaksanaan kegiatan ini adalah:

a. Guru Mampu memahami dan terampil dalam menyusun PTK

b. Guru mampu melaksanakan Penelitian Tindakan Kelas.

\subsection{Metode Pelaksanaan}

Menghadapi masalah yang diatas, maka penulis melakukan pemberian pelatihan tentang Penelitian Tindakan Kelas. Dalam pemberian pelatihan penelitian tindakan kelas didalamnya terdapat pelatihan pembuatan proposal dan laporan PTK dan juga bagaimana membuat karya ilmiah. Berikut pelaksanaan kegiatan pemberian Pelatihan Penelitian Tindakan Kelas:

Tabel 1. Pelaksanaan Pemberian Pelatihan PTK

\begin{tabular}{llll}
\hline \multicolumn{1}{c}{ Materi Kegiatan } & \multicolumn{1}{c}{ Penyaji } & Ket. \\
\hline $\begin{array}{l}\text { Konsep dasar Penelitian Tindakan } \\
\text { Kelas }\end{array}$ & $\begin{array}{l}\text {-Dr. Andi Syukriani, M.Pd. } \\
\text {-Dr. Elpisah, M.Pd. }\end{array}$ & Teori \\
\hline $\begin{array}{l}\text { Karakteristik Penelitian Tindakan } \\
\text { Kelas }\end{array}$ & $\begin{array}{l}\text {-Dr. Elpisah, M.Pd. } \\
\text {-Dr. Andi Syukriani, M.Pd. }\end{array}$ & Teori \\
\hline $\begin{array}{l}\text { Tujuan dan manfaat Penelitian } \\
\text { Tindakan Kelas }\end{array}$ & -Alfiah Nurfadhilah AM. Hindi, S.Pd., M.Pd. & Teori \\
\hline
\end{tabular}

\section{Hasil dan Pembahasan}

Pelaksaan pelatihan ini terdiri atas tiga tahapan yaitu tahap perencanaan, tahap pelaksanaan, dan tahan evaluasi dan pelapolran. Keseluruhan tahapan dilkasanakan dalam jangka waktu 6 (enam) bulan, satu bulan tahap perencanaan mulai pada bulan november 2019 dan selanjutnya tahap pelaksanaan sampai tahap evaluasi dan pelaporan.

\section{a. Tahap perencanaan}

Ide pelatihan ini muncul dari kondisi masyarakat khususnya para guru yang belum mahir dalam melakukan penelitian. Penelitian yang harus dilakukan oleh setiap guru adalah penelitian tindakan kelas (PTK). Ide tersebut kemudian direalisasikan, didiskusikan dengan rekan sejawat dosen, dan ditemukanlah solusi yaitu pelaksanaan pelatihan karya ilmiah penelitian tindakan kelas (PTK) bagi guru. Setelah tema pelatihan ditemukan, dimulailah persiapan-persiapan seperti merancang proposal, persiapan materi pelatihan, menyusun jadwal, konfirmasi narasumber/pemateri, persiapan administrasi kegiatan, dan konfimasi kepada mitra (sekolah) serta kesiapan tempat pelatihan. Rencana pelaksanaan dan jadwal pelatihan diinformasikan kepada pihak mitra melalui media sosial, SMS/WA, informasi langsung secara lisan, dan melalui pemasangan spanduk.

\section{b. Tahap pelaksanaan}

Tahap pelaksanaan sesuai dengan jadwal yang telah direncanakan yaitu pada tanggal 6 januari 2020 - 7 januari 2020 . Pada tanggal 6 januari 2020 dilakukan kegiatan berupa pemberian materi : (1) pengenalan penelitian ilmiah selama 2 jam; (2) Pelatihan penulisan karya ilmiah selama 2 jam. Kemudian dilanjutkan dengan kerja mandiri. Selanjutnya pada tanggal 7 januari 2020 dilanjutkan dengan pemberian materi tentang penelitian tindakan kelas (PTK) dan kerja mandiri.

Respon peserta pelatihan saat pelaksanaan pelatihan sangat baik. Seluruh peserta begitu memperhatikan setiap penjelasan. Total peserta yang mengikuti kegiatan ini sebanyak 16 orang guru yang berstatus guru honorer di SMA 
Negeri 3 Takalar. Terlihat peserta sangat antusias dan bersemangat selama pemberian pelatihan. Sejak awal kegiatan pembukaan pada tanggal 6 januari 2020 hingga kegiatan akhir pada tanggal 7 januari 2020. Peserta pelatihan menyimak dengan baik, serius memperhatikan setiap penjelasan, contoh, dan aktif dalam pelaksanaan penelitian. Terdapat beberapa peserta yang bertanya terkait penelitian tindakan kelas. Pertanyaan tersebut disampaikan oleh peserta yang memiliki rencana melalukan penelitian tindakan kelas (PTK).

Adapun suasana kegiatan pelatihan karya ilmiah penelitian tindakan kelas bagi guru di SMA negeri 3 Takalar dapat dilihat dari beberapa gambar berikut:

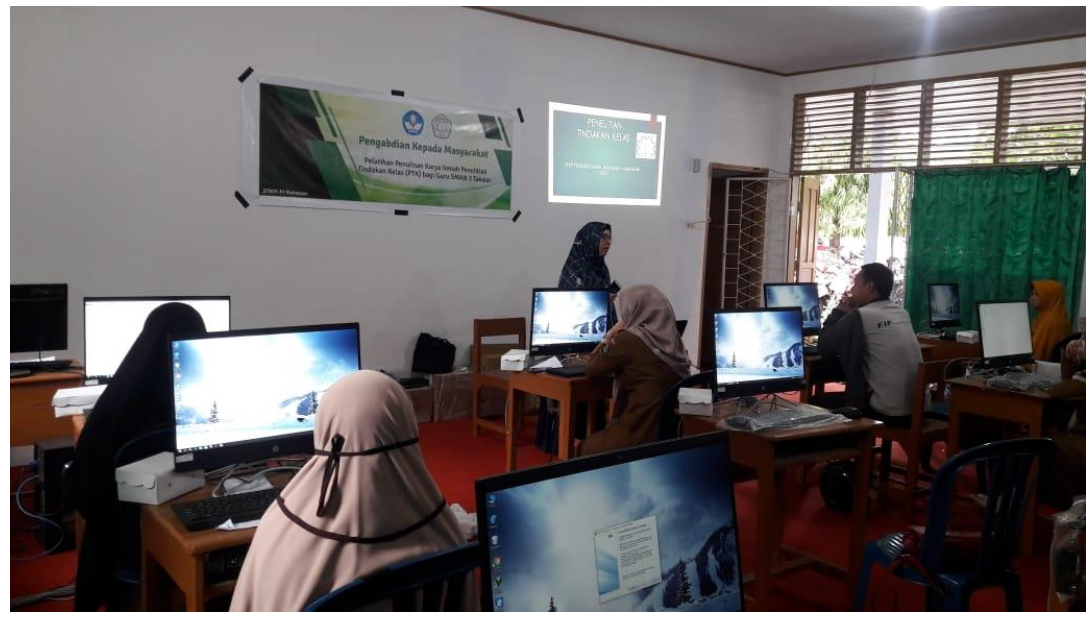

Gambar 1. Suasana Pelatihan

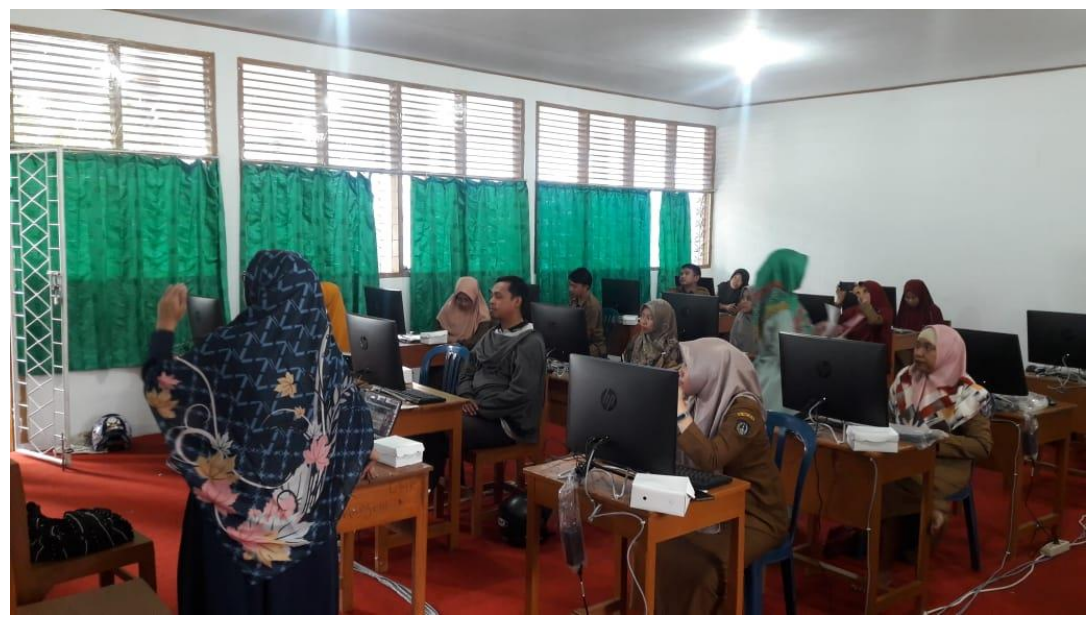

Gambar 2: Peserta Pelatihan Menerima Materi

c. Tahap evaluasi dan pelaporan

Evaluasi yang digunakan untuk mengetahui peningkatan pengetahuan dan keterampilan peserta pelatihan karya ilmiah penelitian tindakan kelas yaitu dengan memberikan tugas mandiri kepada peserta pelatihan berupa membuat proposal penelitian tindakan kelas secara berkelompok. Selama proses kerja mandiri tersebut, peserta senantiasa berkonsultasi kepada para pemateri dan anggota tim pelaksana pelatihan jika ada masalah dan hal-hal yang masih 
kurang dipahami oleh peserta pelatihan. Dari hasil pengerjaan tugas mandiri tersebut nampak bahwa sebagian peserta sudah mampu memahami prosedur pembuatan karya ilmiah penelitian tindakan kelas (PTK).

\section{Kesimpulan}

Berdasarkan pemaparan pada hasil dan evaluasi kegiatan disimpulkan bahwa kegiatan ini dapat meningkatkan pengetahuan dan kemampuan peserta pelatihan dalam membuat karya ilmiah penelitian tindakan kelas (PTK) khususnya dalam pembuatan proposal peneltiian tindakan kelas. Selain itu, para peserta mampu menyusun tulisan penelitian tindakan kelas (PTK) sesuai dengan prosedur yang telah disampaikan pada pelatihan.

\section{References}

Adijaya, Nuryansyah and Prayogo, H, Sulistio. 2013. The Evaluation of Classroom Action Research Articles Written by Indonesian Academics: A Corpus-Based Study. The 60thTeflin: Achieving International Standards in Teacher Education (620-624).

Hunaepi, dkk. 2016. Pelatihan Penelitian Tindakan Kelas (PTK) dan Teknik Penulisan Karya Ilmiah Bagi Guru Di MTs. NM Mertaknao. Lumbung Inovasi: Jurnal Pengabdian Kepada Masyarakat, 1(1) hal. 2.

Mulia, D. S., \& Suwarno, S. 2016. PTK (Penelitian Tindakan Kelas) Dengan Pembelajaran Berbasis Kearifan Lokal Dan Penulisan Artikel Ilmiah Di Sd Negeri Kalisube, Banyumas. Khazanah Pendidikan, 9(2).

Ni’mah, Z. A. (2017). Urgensi Penelitian Tindakan Kelas Bagi Peningkatan Profesionalitas Guru: Antara Cita dan Fakta. Realita, 15(2), 1-22.

Rozi, M. 2015. Guru dan Persoalan Menulis PTK. diambil dari http://www.kompasiana.com/rujakcingurdaribraggroad/guru-dan-persoalan-menulis-ptk _552928086ea8346e728b45ba.

Ulia, N., KD, R. F., Ismiyanti, Y., Yustiana, S., Jupriyanto, J., \& Cahyaningtyas, A. P. (2019). Pendampingan kelompok guru SD di kecamatan Genuk tentang pemahaman metodologi penelitian pendidikan (action research \& experiment) dan penyusunan artikel jurnal. Indonesian Journal of Community Services, 1(1), 3247. 